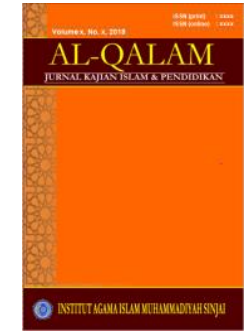

AL-QALAM

Jurnal Kajian Islam \& Pendidikan

Volume 8, No. 2, 2016

ISSN (print) : 1858-4152

ISSN (online) : xxxx-xxxx

Homepage : http://journal.iaimsinjai.ac.id/index.php/al-qalam

\title{
TANTANGAN BUDAYA GLOBAL DAN PERANAN GURU DALAM KURIKULUM 2013
}

\author{
Oleh : Pagga ${ }^{1}$ \\ $* * *$
}

\begin{abstract}
Abstrak
Kurikulum 2013 memiliki content yang mengintegrasikan pembelajaran dengan realitas peserta didik dalam artian mengubah penguasaan teori menjadi aksi nyata. Komponen pembelajaran menekankan pembentukan sikap, keterampilan, pengetahuan. Semua mata pelajaran diajarkan dengan pendekatan saintific dan penilaian otentik melalui mengamati, mencoba, menanya dan menalar, serta mengkomunikasikan. Isu dan problem sentral guru dalam kurikulum 2013 ini tidak lain peranannya yang harus optimal. Nampaknya butuh pencermatan tentang substansi pendidikan dalam kurikulum sebab dari sanalah kita dapat menilai potensi yang harus dioptimalkan. Budaya global membuat perubahan dalam pendidikan secara simultan seperti perubahan sistem dan tujuan pendidikan, teknis pembelajaran dan perubahan substansi pendidikan.
\end{abstract}

KATA KUNCI : Budaya Global, Peranan Guru, Kurikulum 2013

\section{PENDAHULUAN}

O uru memiliki peran sentral dalam dunia pendidikan formal perannya sebagai fasilitator dan sekaligus sebagai penentu kualitas pendidikan bagi peserta didik. Undang Undang Guru dan Dosen No 14 tahun 2005 menegaskan tugas dan peran guru secara eksplisit dan mendalam, ${ }^{2}$ ini menandakan guru sebagai faktor determinan derajat pendidikan bangsa. Secara subjektif guru juga memiliki derajat mulia karena tugasnya, bahkan Nabi Muhammad SAW sangat menghargai peranan dan tugasnya yang mulia dengan menyandingkan derajat kenabiannya dengan derajat guru.

Pengertian diatas menegaskan peran signifikan guru dalam proses pendidikan di lembaga formal, peran mulia itu bukan sesuatu yang sederhana dilakukan oleh guru jika tidak disertai oleh kebijakan dan system pendidikan yang dinamis. Konsekwensi lain yang harus diterima oleh guru adalah mutu dan perannya dituntut maksimal dalam tantangan global ini. Kemajuan ilmu pengetahuan dan tekhnologi serta tata nilai budaya global memberi efek serius sehingga mesti proaktif untuk tidak ketinggalan dalam mencari format penyesuaian.

\footnotetext{
${ }^{1}$ Dosen Institut Agama Islam (IAI) Muhammadiyah Sinjai

${ }^{2}$ Guru sebagai pendidik profesional dengan tugas utama mendidik, mengajar, membimbing, mengarahkan, melatih, menilai dan mengevaluasi peserta didik pada pendidikan usia dini jalur pendidikan formal, pendidikan dasar dan menengah, (BAB 1 Pasal 1). Pada pasal 6 undang-undang tersebut termaktub makna bahwa guru sebagai tenaga profesional yang disebutkan dalam konstitusi berfungsi sebagai agen pembelajaran dan ikut meningkatkan mutu pendidikan Nasional yang bertujuan untuk mengembangkan peserta didik menjadi manusia yang beriman, bertakwa, berakhlak mulia, sehat, berilmu, cakap, kreatif, mandiri serta menjadi warga negara yang demokratis dan bertanggung jawab. Lihat Undang-Undang tentang Guru dan Dosen Nomor 14 tahun 2005,Pasal 6.
} 
Perubahan sistem kurikulum pendidikan yang kompleks memberikan warning bagi guru untuk segera berbenah. Selama ini guru sering dikesankan sebagai actor yang kurang cepat mengikuti perubahan dunia, ketinggalan informasi dan wawasan yang kurang mencerahkan dan membangkitkan potensi anak didik. Pada akhirnya hanya ditempatkan pada posisi tertinggi namun tanpa penghargaan yang berarti. Realitas ini harus diakhiri melihat tantangan global sangat kompleks yang memerlukan kedalaman pengetahuan, keluasan cakwarala pemikiran, kecepatan mengambil keputusan agar tetap relevan, efektif dan kontekstual $^{3}$.

Indikasi diatas, guru sangat diperhadapkan pada tantangan yang multi kompleks. Berbagai upaya telah dilakukan untuk mendorong kinerja dan mutu guru baik melalui program sertifikasi maupun training kompetensi lainnya, hal ini dicontohkan Kemendikbud bahkan berupaya keras mendorong kompetensi guru melalui program Ujian Kompetensi Guru $(\mathrm{UKG})^{4}$, ini tentu bertujuan sebagai upaya penguatan kompetensi dan sikap profesionalismenya.

Salah satu poin pokok diantara lima permasalahan utama dalam Renstra (Rencana Strategi) Pendidikan Nasional yang diprioritaskan yaitu pendidikan berkarakter untuk menumbuhkembangkan nilai-nilai filosofis dan mengembangkan seluruh karakter bangsa secara utuh dan menyeluruh. ${ }^{5}$ Pengembangan karakter bangsa dalam Renstra diatas, diimplementasikan pemerintah dalam kurikulum 2013. Kurikulum 2013 yang berbasis karakter ini strukturnya mencakup standar SKL, standar isi, standar proses, standar tenaga pendidik dan standar penilaian. Pendidikan karakter diintegrasikan dalam seluruh pembelajaran, pendidikan nilai dalam pembentukan karakter tidak hanya dilakukan pada tataran kognitif, tetapi menyentuh internalisasi, dan pengamalan nyata dalam kehidupan sehari-hari.

Ingatan kita pada 2 tahun silam pernah diterapkan kurikulum 2013 yang silih berganti dengan KTSP tentunya diharapkan peserta didik dimasa yang akan datang bermodalkan nilainilai pendidikan secara holistik. Menurut Head of Research \& Defelopment Santa Laurensia Jeani Budiawati Tjandiagung bahwa kurikulum 2013 memiliki dasar yang sangat bagus, hal ini bisa dilihat dari content yang didalamnya terpusat pada pengembangan kompetensi dan kemampuan karakter. Lebih lanjut menuturkan pada masa depan, Indonesia membutuhkan anak bangsa yang memiliki kekuatan pada 4C yaitu, critical, creative, communicative, dan critical thingking. ${ }^{6}$

\footnotetext{
3Jamal Ma'mur Asmani, Kompetensi Guru Menyenangkan dan Profesional, (Yogyakarta, Power Books, 2009), hlm. 15-16

${ }^{4}$ Data yang dipaparkan Dirjen Guru dan Tenaga Kependidikan, hasil UKG 2012-2014 menunjukkan, dari 1.611.251 orang guru TK, SD, SMP, SLB, SMA dan SMK rerata nilai tertinggi 90,1-100 hanya dicapai 192 orang guru. Pada umumnya, nilai UKG para guru berkisar nilai 30,1-40 dan 40,1-50. Pada nilai UKG guru non PNS di sekolah negeri paling rendah yaitu guru honorer daerah nilai rerata 41,9 dan guru tidak tetap sekolah negeri (GTT) nilai reratanya 43,8. Nilai yang rendah inilah yang menjadi dasar perlunya meningkatkan kompetensi guru. Lihat Harian Kompas, Uji Kompetensi Guru dan Mutu Pembelajaran. Edisi Rabu 25 November 2015,

${ }^{5}$ E. Mulyasa, Pengembangan dan Implementasi Kurikulum 2013, (Bandung:Remaja Rosda Karya, 2013), hlm 5 .

${ }^{6}$ Lihat, Umar dkk, Landasan Konseptual Pengembangan Kurikulum; Sebuah Tinjauan Kritis, Makalah tidak diterbitkan. Lihat juga Koran Harian Kompas, Rabu, 18 September 2013, dalam Mengupas Sisi Positif Kurikulum 2013,
} 


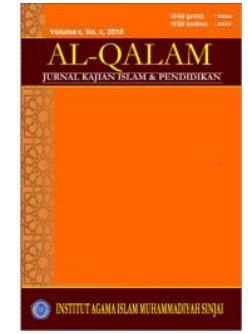

AL-QALAM

Jurnal Kajian Islam \& Pendidikan

Volume 8, No. 2, 2016

ISSN (print) : 1858-4152

ISSN (online) : xxxx-xxxx

Homepage : http://journal.iaimsinjai.ac.id/index.php/al-qalam

Mengaitkan tantangan masa depan peserta didik yang seharusnya memiliki kekuatan critical, creative, communicative, dan critical thingking maka K-13 diatas yang implementasi menuntut guru untuk berbenah secara optimal melalui pembelajaran yang menekankan keseimbangan sikap, keterampilan dan pengetahuan sehingga terwujud peserta didik yang produktif, inovatif, kreatif dan afektif memiliki softskill dan hard skill yang tangguh. Keseimbangan seperti inilah yang perlu dimiliki oleh peserta didik sebagai bekal menghadapi derasnya pusaran budaya global.

Isu dan problem sentral guru dalam kurikulum 2013 ini tidak lain peranannya yang harus optimal. Nampaknya butuh pencermatan tentang substansi pendidikan dalam kurikulum sebab dari sanalah kita dapat menilai potensi yang harus dioptimalkan.

Berdasarkan paradigma diatas dapat dirumuskan beberapa permasalahan yang perlu dijawab dalam pembahasan berikut ini yaitu; (1) Bagaimana potret guru dan peranannya dalam berbagai tinjauan perspektif, (2) Bagaimana kurikulum 2013 dan kesiapan guru, (3) Apa tantangan budaya global dalam dunia pendidikan?, dan (4) Bagaimana peran guru dalam tantangan global?. Tulisan mencoba memecahkan problem tersebut melalui pendekatan Undand-undang dan literature pendidikan dengan kajian kurikulum 2013 yang berkaitan dengan tatangan budaya globalisasi. Selain menjawab permasalahan diatas diharapkan dapat menjadi satu konstruk paradigmatik bagi guru sebagai upaya mengoptimalisasi peranannya yang senantiasa diperhadapkan pada tantangan yang kian berubah-ubah.

\section{PEMBAHASAN}

\section{Guru dan Peranannya dalam Berbagai Tinjauan Perspektif}

Undang-Undang Guru dan Dosen No.14 tahun 2005 yang telah diundangkan pada 30 Desember 2005 memiliki substansi bahwa pekerjaan guru hanya dapat dilakukan oleh seseorang yang mempunyai kualifikasi akademik, kompetensi, dan sertifikat pendidik sesuai dengan persyaratan untuk setiap jenis dan jenjang pendidikan tertentu. Guru sebagai tenaga profesional berfungsi untuk meningkatkan martabat dan perannya sebagai agen pembelajaran. $^{7}$

Sebelumnya Undang Undang No. 20 tahun 2003 tentang Sisdiknas menempatkan posisi guru sebagai tenaga pendidik yang aktif dalam menyelenggarakan pendidikan. Guru dalam penjelasan undang-undang ini adalah sebagai pendidik yaitu tenaga kependidikan yang berkualifikasi sebagai guru, dosen, konselor, pamong belajar, widyaiswara, tutor, instruktur, fasilitator, dan sebutan lain yang sesuai dengan kekhususannya, serta berpartisipasi dalam menyelenggarakan pendidikan.

Esensi pengertian diatas menandakan guru adalah tugas dan beban yang tidak mudah, lalu bagaimana peran guru selama ini?. Sekilas, jika merujuk sejarah pendidikan bangsa Indonesia guru memiliki peranan substansial dimana guru sebagai pendidik yang mengajarkan nilai-nilai kehidupan bagi anak-anak pribumi, terutama di lembaga pendidikan Islam (pondok pesantren) para guru ini disebut dengan kiyai/ustad. Sedangkan dizaman penjajahan peran guru sangat penting dalam membangkitkan semangat kebangsaan Indonesia

\footnotetext{
${ }^{7}$ Yang dimaksud dengan guru sebagai agen pembelajaran (learning agent) adalah peran guru antara lain sebagai fasilitator, motivator, pemacu, perekayasa pembelajaran, dan pemberi inspirasi belajar bagi peserta didik. Kompetensi guru sebagaimana dimaksud dalam pasal ini meliputi kompetensi pedagogik, kompetensi kepribadian, kompetensi sosial, dan kompetensi profesional yang diperoleh melalui pendidikan profesi. Lihat, Nanat Fatah Natsir, "Peningkatan kualitas Guru dalam Perspektif Islam" dalam jurnal EDUCATIONIST No. I Vol. I Januari 2007.
} 
menuju cita-cita kemerdekaan. Sebagai pengajar dan pendidik yang berhadapan langsung dengan siswa, maka guru secara langsung menanamkan jiwa nasionalisme dan menekankan arti penting sebuah kemerdekaan bagi bangsa Indonesia. ${ }^{8}$

Dari zaman ke zaman peran guru mengalami perubahan, misalnya menjelang kemerdekaan guru berperan sebagai pembangkit semangat bagi anak didiknya untuk berpartisipasi aktif dalam perebutan kemerdekaan, guru banyak mengajarkan pentinganya nasionalisme dan kemerdekaan agar bangsa dapat terbebas dari kaum penjajah, kaitan dengan pengajaran seperti ini masih mendominasi proses pembelajaran dikelas, sebab masih sedikitnya mata pelajaran yang dapat dijarkan di sekolah-sekolah rakyat.

Pasca kemerdekaan guru banyak menekankan pembelajaran tentang pentingnya mengisi kemerdekaan, baik pembangunan yang bersifat fisik dan pembangunan sumber daya manusia. Anak didik yang seteleh dewasa diberi kesempatan menjadi pelopor pembangun daerah dan masyarakatnya bahkan dapat menjadi pengajar dilembaga non formal maupun pejabat publik. Peran guru yang lain adalah sebagai panutan, menyandang profesi guru ibarat mempengaruhi orang di lingkungannya sebab memiliki kharismatik yang baik, ia sebagai suri teladan bagi keluarganya, lingkungan tempat tinggal maupun masyarakatnya secara umum. Guru identik dengan pejabat publik dimana masyarakatnya akan mengikuti tindakannya jika memiliki integritas, tanggung jawab maupun kinerja yang baik.

Masa orde baru hingga reformasi guru tetap dianggap pelaku utama perubahan dalam dunia pendidikan bahkan dibaratkan sebagai "pahlawan tanpa tanda jasa". Dalam konteks kekinian tetap menempati posisi urgen sebab guru adalah pelaku transformasi ilmu pengetahuan baik berkaitan ilmu alam, ilmu hitung, bahasa, keterampilan dll. Pada tataran praktisnya ini guru banyak menekankan penguasaan ilmu-ilmu tersebut sebagai bekal kemampuan anak didik menghadapi kehidupan masa depan. Posisi guru disini adalah pusat informasi pengetahuan sebab pembelajarannya menfokuskan guru sebagai sumber informasi dan dianggap kurang mengembangkan potensi kreatifitas siswa. Pembelajarannya masih mendominasi aspek kognitif dan psikomotorik dan sedikit menekankan pembelajaran afektifnya sehingga output yang dihasilkan ibarat sekolah adalah penghasil robot. Pada tataran aplikatifnya system pendidikan ini banyak menuai kritikan banyak pihak sehingga menawarkan pentingan perubahan system kurikulum pendidikan yang menyeimbangkan ketiga aspek tersebut salah satunya adalah kurikulum 2013.

Pada konteks lain pendidikan Islam tampil dengan formatnya jika guru memiliki peran ganda yang sangat diperhitungkan dimasa kini. Suatu kalimat telah mengilustrasikan "guru sejatinya adalah seorang pribadi yang harus serba bisa dan serba tahu" serta mampu mentransferkan kebiasaan dan pengetahuan pada muridnya dengan cara yang sesuai dengan perkembangan dan potensi anak didik. Jika didasarkan pada bahasa Arab guru berarti almualim terdapat kata yang lain seperti murabbi (mendidik), mudarris (pengajar) dan uztadz. Secara terminology pakar pendidikan berpendapat misalnya Ahmad Tafsir, pendidik dalam Islam adalah orang yang bertanggung jawab terhadap perkembangan peserta didik dengan upaya mengembangkan seluruh potensi peserta didik, baik potensi afektif (rasa), kognitif

${ }^{8}$ Kunandar, Guru Profesional, Jakarta:Raja Graphindo Persada, 2007, hlm 30-31.

${ }^{9}$ Peran dan Fungsi Guru dalam website, http://edukasi.kompasiana.com /2012/07/18/. Diakses, 22 September 2012. 

bapak rohani (spiritual father) bagi peserta didik, yang memberikan santapan jiwa dengan ilmu, pembinaan akhlak mulia, dan meluruskan prilakunya yang buruk. ${ }^{11}$

Menengok peran guru disini, nampaknya konteks pendidikan Islam memberikan pengertian berbeda yakni menempatkan guru sebagai pengajar ilmu pengetahuan sekaligus pendidik dan suri teladan yang baik yang dicontoh dan mencontoh dalam segala hal. Sedangkan analogi dalam dunia persekolahan guru diposisikan sebagai pengajar yang tugasnya mengisi ilmu pengetahuan ke dalam otak peserta didik yang dianalogikan konsep gaya bank banking concept sebagaimana diistilahkan Paulo Freire tokoh pendidikan kritis Barat, dimana guru melakukan deposito berbagai macam informasi tanpa harus tahu untuk apa informasi tersebut bagi kehidupan mereka ${ }^{12}$.

Seiring dengan perkembangan globalisasi dan perubahan paradigma pendidikan dimasa sekarang, peran guru berkembang lebih kreatif dimana awalnya pembelajaran berorientasi pada guru sebagai pusat informasi bergeser pada peserta didik yang berkreatif dan berimajinatif hal ini dikarenakan banyaknya alternatif sumber belajar yang dapat diakses oleh siswa dan guru dianggap sebagai fasilitator pembelajaran. Selain itu pembelajaran dilakukan dengan pendekatan integratif, metode klasikal, fleksibel dan aktif terpadu sebagaimana banyak digunakan di sekolah boarding school dan full day serta pembelajaran yang e-learning dengan memanfaatkan media sosial.

Perkembangan iptek banyak menjadikan manusia tampil kreatif dan kompetitif, terlebih guru dalam mengupayakan pendekatan, metode dan strategi pembelajaran dengan menekankan kemampuan problem solving dan kreatif. Oleh karena itu guna mengharapkan hasil pendidikan sesuai dengan kebutuhan di era globalisasi ini, pembelajaran pendidikan perlu didasarkan pada empat pilar proses pendidikan pembelajaran, yaitu learning to know, learning to do, learning to be dan learning to live together ${ }^{13}$. Hal ini sesuai dengan pendapat Ramayulis bahwa kegiatan pembelajaran beberapa prinsip yang harus diperhatikan oleh guru/pendidik sebelum melakukan proses pembelajaran, yaitu: ${ }^{14}$ (1) berpusat pada peserta didik, (2) belajar dengan melakukan, (3) mengembangkan kemampuan sosial, (4) mengembangkan keingintahuan, (5) mengembangkan fitrah bertuhan, (6) mengembangkan keterampilan pemecahan masalah, (7) mengembangkan kreatifitas peserta didik.

\section{Kurikulum 2013 dan Kesiapan Guru}

Merujuk sejarahnya, Istilah kurikulum digunakan pertama kali pada dunia olahraga pada zaman Yunani kuno, berasal dari kata curir dan curere yang diartikan sebagai jarak yang harus ditempuh oleh seorang pelari dari mulai start hingga finish.${ }^{15}$ Dalam bahasa Arab, istilah kurikulum diartikan dengan manhaj, yakni jalan yang terang, atau jalan yang terang yang dilalui oleh manusia pada bidang kehidupannya. ${ }^{16}$ Dalam konteks pendidikan,

\footnotetext{
${ }^{10}$ Ahmad Tafsir, Ilmu Pendidikan dalam Perspektif Islam, (Bandung: Remaja Rosdakarya, 1992), hlm,74-75.

${ }^{11}$ Abdul Mujib. Ilmu Pendidikan Islam. (Jakarta: Kencana Prenada Media,2006), hlm.88.

${ }^{12}$ Kunandar, Guru.., hlm. 63.

${ }^{13}$ Hamzah B. Uno, Profesi Kependidikan, problem, solusi dan reformasi pendidikan di Indonesia, Jakarta:Bumi Aksara, hlm.105-108

${ }^{14}$ Ramayulis, Metodologi Pendidikan Agama Islam, Jakarta: Kalam Mulia, 2012, hlm97-105

${ }^{15}$ Wina Sanjaya, Kurikulum dan Pembelajaran Teori dan Praktik Pengembangan Kurikulum Tingkat Satuan Pendidikan (KTSP), (Jakarta: Kencana Prenada Media Group, 2009), hlm. 3.

${ }^{16}$ Ramayulis, Ilmu Pendidikan Islam (Jakarta : PT. Kalam Mulia, 2004), hlm. 128.
} 
kurikulum berarti jalan terang yang dilalui oleh pendidik/guru dengan peserta didik untuk mengembangkan pengetahuan, keterampilan dan sikap serta nilai-nilai. ${ }^{17}$ Pakar pendidikan barat seperti Hilda Taba (1962) dalam bukunya Curriculum Development, Theori and Practice, mendefinisikan "a curriculum is a plan for learning", ${ }^{18}$ kurikulum yaitu perencanaan untuk belajar atau sesuatu yang direncanakan untuk pelajaran anak.

Pengertian kurikulum diatas mengisyaratkan pentingnya perencanaan dalam proses belajar mengajar melalui transformasi pengetahuan, keterampilan dan nilai. Kurikulum pendidikan kita sebagaimana dijelaskan dalam Undang-Undang Nomor 20 Tahun 2003 tentang Sisdiknas ${ }^{19}$ ini telah mengatur rencana pembelajaran sebagai suatu kurikulum dalam pelaksanaan pendidikan. Substansi kurikulum mengandung nilai filosofis, bertujuan mewujudkan peserta didik sebagai manusia yang utuh memiliki keterampilan, berkarakter dan bertakwa sesuai dengan ajaran agamanya. Hal ini sangat erat kaitannya khususnya kurikulum 2013 yang banyak menyita perhatian selama ini.

Perubahan kurikulum pada lembaga pendidikan, sebelumnya kurikulum 2006 (KTSP), kini telah berubah nama dengan kurikulum 2013 dan telah resmi diberlakukan dengan payung hukum PP No 32 Tahun 2013 perubahan PP No 19 Tahun 2005 tentang Standar Nasional Pendidikan. Penyesuaian kurikulum ini membawa pesan nilai yang relevan dengan masa sekarang, yaitu pendidikan karakter yang berbasis pada hati nurani dan agama. Dalam kurikulum memiliki dua dimensi, pertama adalah rencana dan pengaturan mengenai tujuan, isi, dan bahan pelajaran, sedangkan yang kedua adalah cara yang digunakan untuk kegiatan pembelajaran. Selanjutnya menurut Oemar Hamalik, hal yang menjadi penentu keberhasilan implementasi adalah perencanaan dan strategi implementasinya ${ }^{20}$.

Kurikulum 2013 yang diberlakukan mulai tahun ajaran 2013/2014 memenuhi kedua dimensi tersebut diatas. ${ }^{21}$ Kurikulum 2013 tiap mata pelajaran mendukung semua kompetensi (sikap, keterampilan, pengetahuan), mata pelajaran dirancang terkait dengan yang lain dan memiliki kompetensi dasar yang diikat dengan kompetensi inti tiap kelas, semua mata pelajaran diajarkan dengan pendekatan yang sama (saintific) melalui mengamati, mencoba, menanya dan menalar, mengkomunikasikan. Kurikulum 2013 kegiatan pengembangan silabus beralih menjadi kewenangan pemerintah, kecuali untuk mata pelajaran tertentu yang secara khusus dikembangkan di satuan pendidikan yang bersangkutan, ${ }^{22}$ berbeda dengan KTSP sebelumnya kegiatan pengembangan silabus merupakan kewenangan satuan pendidikan. Obyek pembelajaran dalam kurikulum 2013 adalah fenomena alam, sosial, seni, dan budaya. Melalui pendekatan itu diharapkan siswa kita memiliki kompetensi sikap,

\footnotetext{
${ }^{17}$ Muhaimin, Pengembangan Kurikulum Pendidikan Agama Islam; di Sekolah, Madrasah, dan Perguruan Tinggi, (Jakarta : PT. Raja Grafindo Persada, 2005), hlm. 1.

${ }^{18}$ Hilda Taba, Curriculum Development, Theori and Practice, (New York: Harcourt, Brace \& World, Inc, 1962), hlm. 11.

${ }^{19}$ Kurikulum adalah seperangkat rencana dan pengaturan mengenai tujuan, isi, dan bahan pelajaran serta cara yang digunakan sebagai pedoman penyelenggaraan kegiatan pembelajaran untuk mencapai tujuan pendidikan tertentu. (Lihat, UUD No. 20 tahun 2003 Tentang Sisdiknas).

${ }^{20}$ Oemar Hamalik, Dasar-Dasar Pengembangan Kurikulum, (Bandung: PT Remaja Rosdakarya, 2009), hlm. 190.

${ }^{21}$ Permendikbud No 68 Tahun 2013 Tentang Kerangka Dasar dan Struktur Kurikulum Sekolah Menengah Pertama/ Madrasah Tsanawiyah.

22 Kementerian Pendidikan dan Kebudayaan dalam mata diklat: 2. Analisis materi ajar jenjang:SD/SMP/SMA Mata Pelajaran: Konsep Pendekatan Scientific.
} 
keterampilan, dan pengetahuan jauh lebih baik. Mereka akan lebih kreatif, inovatif, dan lebih produktif, sehingga nantinya mereka dapat meraih masa depan lebih baik.

Lalu sejauh mana kesiapan guru dalam proses pembelajaran khususnya pada implementasi kurikulum 2013 ini?, faktanya penulis belum mendapatkan sejumlah data akurat secara nasional yang terkait kesiapan guru dalam proses pembelajaran pada kurikulum 2013 ini, namun didasarkan pada analisa berbagai literatur mengindikasikan bahwa sebagian besar daerah di Indonesia telah berupaya dalam kegiatan peningkatan kompetensi seperti training guru-guru, dan penguatan kurikulum 2013.

Diantara kesulitan guru dalam kurikulum 2013 ini ialah pemahaman utuh terhadap substansi kurikulum, kemampuan menyusun rencana pembelajaran. Disamping problem implementasinya sebagaimana dijelaskan Mulyasa seperti pendidikan karakter yang diintegrasikan dalam seluruh pembelajaran pada setiap bidang studi. Materi pembelajaran yang berkaitan dengan norma atau nilai-nilai pada setiap bidang study perlu dikembangkan, dieksplisitkan, dihubungkan dengan konteks kehidupan sehari-hari. ${ }^{23}$ Meskipun silabus telah dikembangkan oleh pemerintah pusat, bukan berarti guru menjadi passif dalam memahami substansi dalam silabus untuk persiapan pembelajaran. Dengan demikian,

Pada tataran praktis pembelajaran bekal pelatihan seperti metode saintific (scientific metod) dan penilaian otentik tetap belum mampu mengubah banyak dalam kebiasaan mengajar guru, kesulitan dalam mengubah penguasaan teori menjadi aksi nyata bagi peserta didik tetapi hanya mampu mengintegrasikan pembelajaran dengan kaitan yang lain. Kesulitan dalam mengembangkan kurikulum terlebih guru belum memenuhi kualifikasi kompetensi yang dipersyaratkan dalam kurikulum 2013 seperti kompetensi paedagogik, kompetensi akademik (keilmuan) maupun kompetensi kepribadian.

Pada intinya implementasi kurikulum 2013 disekolah dimana prosesnya yang menekankan pembelajaran kontekstual dengan penilaian yang otentik. Kesiapan guru dalam kurikulum ini dinilai tidak mudah sebab perlu proaktif dan utuh dalam perencanaan dan strategi pembelajaran yang mengintegrasikan hal-hal yang berkaitan dengan keadaan seharihari, baik dari dalam kelas ke keluar kelas maupun sebaliknya serta kaitannya pembelajaran dalam konteks tantangan secara global. Dalam pemaparan Prof. Syawal Gultom Kepala Badan PSDM dan PMP Kemendikbud dalam tayangan TV Edukasi bahwa perlu pemahaman yang utuh tentang kurikulum 2013 ini, kurikulum mementingkan pembentukan sikap secara perlahan-lahan.

\section{Sekilas Tantangan Budaya Global dalam Dunia Pendidikan}

Pada berbagai perbincangan serius mengenai tantangan guru, dengan kekhawatiran yang sering kali muncul dimana peranan guru dimasa kini jauh lebih ekstra dibanding peran guru generasi lebih dulu. Paradigma nilai sebagai pesan yang harus dibawa oleh guru ke hadapan peserta didik yang dulunya massif kuat mendasar telah bergeser akibat budaya global membuat generasi peserta didik tidak mampu mewarisi dan melestarikan tata nilai sebagai falsafah hidup yang baik. Pada sisi lain menurut Heddi Shry Ahimsa Putra ada kebanggaan sendiri terhadap kemampuan generasi muda dalam menyerap budaya luar yang

\footnotetext{
${ }^{23}$ E.Mulyasa, Pengembangan., hlm 4-7
} 
kemudian memanfaatkannya untuk mengembangkan budaya mereka sendiri, ${ }^{24}$ baik dalam meraih cita-cita, perhatian terhadap masalah lingkungan dan lain sebagainya.

Budaya global berkaitan dengan nilai-nilai yang dianut dan diterima oleh sebagian besar masyarakat dunia yang diimplementasikan dalam kehidupan sehari-hari termasuk dalam pendidikan. Heddi Shry Ahimsa Putra menyimpulkan tiga nilai global yang sangat penting bagi generasi muda (peserta didik) yang harus diajarkan oleh guru ialah hak-hak asasi manusia, profesionalisme dan kreatifitas. ${ }^{25}$

Hak asasi manusia berkaitan dengan dimensi kemanusiaan, bonus demografi menjadi peluang sekaligus tantangan dalam skala pendidikan mengakibatkan kompetisi global menjadi tak terhindarkan sehingga berpengaruh terjadinya gesekan dan bahkan konflik horizontal adalah potret yang banyak terjadi. Respon pendidikan pada problem ini sangat melibatkan guru dalam proses pembentukan jiwa kemanusiaan bagi peserta didiknya.

Nilai profesionalisme dan kreatifitas ini sangat erat kaitannya dengan kurikulum pendidikan saat ini sebab keduanya adalah aspek yang harus dipenuhi oleh guru dalam proses pembelajaran, selain mengajarkannya ke peserta didik. Tantangan yang dihadapi oleh guru ini ialah kemampuan professional dan berkreatif untuk dapat berkompetisi ditengah arus global tekhnologi informasi. Sebagai contoh dalam konteks regional Asia, guru dan lulusan pendidikan kita dihadapkan pada tantangan Masyarakat Ekonomi Asean (MEA) dan resmi diberlakukan akhir tahun 2015 dimana tiap individu dituntut untuk profesionalisme dan kreatif agar dapat berkompetisi dalam pasar kerja. Dengan demikian guru penting mewujudkan pembelajaran yang lebih menarik sesuai konten kurikulum, dilain hal guru mau tidak mau harus menyadari kekurangan atas kemampuan profesinya sebagai tantangan yang harus disikapi secara mutlak dan dini.

Pada tantangan yang berbeda, salah satu misi global khususnya dalam dunia pendidikan adalah tantangan sekularisme ${ }^{26}$ yang dinilai bertentangan dengan pandangan ajaran agama-Islam. Asumsi berbeda oleh Budhy Munawar Rahman dalam makalah seminarnya bahwa salah satu kunci kemajuan bangsa Indonesia terletak pada penerapan yang benar ide sekularisme. ${ }^{27}$ Dalam hal ini proses pembelajaran bagi guru penting menyikapi bahwa sekularisme tak selalu memiliki misi yang buruk secular oriented oleh karenanya dalam pendidikan agama adalah perlunya mempertahankan nilai-nilai dan tujuan pendidikan yang sebenarnya yakni dengan menyatukan muatan-muatan positif dari konsep-konsep pendidikan yang sekuler sebagai pendukung kekuatan dalam kurikulum. Lebih lanjut Budhy Munawar menjelaskan hal terpenting bagi bangsa Indonesia sekarang ini memilih modelmodel sekularisme yang sesuai dengan konteks dan karakter dasar ke-Indonesiaan tanpa

${ }^{24}$ Heddi Shry Ahimsa Putra, Sumber Nilai Budaya dan Nilai Budaya untuk Generasi Muda Indonesia, Makalah disampaikan dalam Kongres Pendidikan, Pengajaran dan Kebudayaan II, di Yogyakarta 5 Mei 2014 , hlm. 1

${ }^{25}$ Ibid, Heddi Shry Ahimsa Putra, Sumber...,hlm. 5.

${ }^{26}$ Paham atau pandangan filsafat yang berpendirian bahwa moralitas tidak perlu didasarkan pada ajaran agama. Lihat Suharso dan Ana Retnoningsih, Kamus Besar Bahasa Indonesia Edisi Lux, (Semarang: Widiya Karya, 2011), hlm. 468.

${ }^{27}$ Budhy Munawar Rahman, Sekularisme, Liberalisme, Pluralisme dan Islam Progresif Indonesia, Makalah Seminar di Convention Hall UIN Sunan Kalijaga Yogyakarta, tanggal 18 September 2013, hlm. 18. Lebih lanjut dijelaskan ada banyak model sekularisme disetiap tempat dan setiap waktu, namun perbedaan muncul karena konsep filosofisnya memang tidak stagnan, selalu ada koreksi terhadap konsepnya sendiri, sehingga perlu pemahaman yang dinamis mengenai sekularisme. 

sendiri sesuai dengan pandangannya, namun harus tetap dalam rambu-rambu kebangsaan, kebernegaraan dan matched dengan tantangan kehidupan lokal dan global.

Tantangan lain juga berupa lemahnya penanaman sikap toleransi yang harus memperkokoh nilai ke-bhinneka tunggal ikaan, kesadaran nasionalisme dalam kehidupan sehari-hari terasa lemah mengakibatkan sebagian besar generasi muda (peserta didik) kurang percaya diri pada budaya dan daerahnya bahkan bangsanya, fokus dan larut pada dinamika dan pesona global tetapi kurang pemahaman akan wawasan kebangsaan bahkan nyaris kehilangan kesadaran sejarah.

Kekhawatiran atas pandangan tentang contoh tantangan global tersebut juga masih diiringi oleh sejumlah sikap optimisme guru serta dalam berbagai upaya mempersiapkan diri seperti perubahan mindset dan mental yang dapat dicontoh dan mencontoh, penguatan kompetensi, strategi dan metodologi pembelajaran melalui sumber tekhnologi informasi untuk menyambut tantangan-tantangan baru dan selalu berubah-ubah.

\section{Peranan Guru dalam Tantangan Budaya Global}

Optimalisasi peranan guru dalam tantangan budaya global ini relevan dengan harapan sahabat Nabi SAW, Ali bin Abi Thalib r.a, yakni: "didiklah anak-anak kalian tidak seperti yang didikkan kepada kalian sendiri, karena ia diciptakan untuk generasi zaman yang berbeda dengan generasi zaman kalian." Harapan tersebut dapat menjadi titik tolak proses pembelajaran dengan membekali peserta didik berbagai pengetahuan, keterampilan dan karakter yang baik. Dalam kurikulum 2013 menformulasikan jangkauan ke masa depan pendidikan bagi peserta didik. Dari paradigma tersebut upaya optimalisasi peranan guru dapat mencakup beberapa lingkup pokok yaitu:

Pertama, Optimalisasi kompetensi, ${ }^{30}$ setiap kompetensi bersifat holistik dan integratif sehingga mutlak mendapatkan perhatian sepenuhnya oleh guru, hal-hal yang berkaitan

${ }^{28}$ Ibid., Budhy Munawar Rahman, Sekularisme..,

${ }^{29}$ Mastuhu, Menata Ulang Pemikiran Sistem Pendidikan Nasional dalam Abad 21, (Yogyakarta: Safiriah Insania Press, 2004), hlm. 105.

${ }^{30}$ Dalam hal ini UU Guru dan Dosen No. 14 Tahun 2005, menegaskan 4 kompetensi guru meliputi, kompetensi paedagogik yang mencakup kemampuan guru pengelolaan pembelajaran, kompetensi kepribadian mencakup personalitas sikap dan akhlak guru, kompetensi sosial mencakup relasi dan interaksi guru dengan masyarakat, kompetensi professional mencakup penguasaan pengetahuan dan keilmuan guru. Selain itu Jamal Ma'mur Asamani menambahkan kompetensi global sebagai kompetensi yang sangat penting, didalamnya mencakup kemampuan dalam berprestasi dalam lingkup global. Lihat, Jamal Ma'mur Asamani, 7 Kompetensi.. hlm. 43-49. Dalam kurikulum 2013, perubahan dan optimalisasi peran guru yang mendasar dibagi kedalam beberapa aspek, yaitu: (1) Aspek filosofis dalam tataran praktis yang selama ini difahami guru adalah sebagai satu-satunya sumber belajar yang ada di kelas dan siswa sebagai objek belajar yang siap menerima apapun yang dikatakan guru, namun dalam kurikulum 2013 guru sebagai salah satu sumber belajar dari sekian sumber yang ada termasuk siswa. Dan siswa sebagai subjek belajar yang dapat berpartisipasi dalam mengkonstuksi ilmu pengetahuan yang dipelajari di kelas. (2) Aspek professional. Kurikulum 2013 memberikan kelonggaran kepada guru dalam mengembangkan kurikulum karena seluruh perangkat kurikulum mulai dari silabus dan buku babon sudah disediakan oleh pemerintah, serta tujuan, kompetensi yang akan dicapai dan kompetensi dasarnya sudah disiapkan. Tugas guru hanya mengembangkan kurikulum yang disesuaikan dengan kondisi dan kebutuhan peserta didik yang dituangkan dalam indikator dan tersurat dalam RPP. Sedangkan penilaian yang dilakukan oleh guru tidak hanya dari hasil kerja peserta didik, namun juga memperhatikan proses yang meliputi pengetahuan, ketrampilan dan sikap dalam menghasilkan produk. (3) Aspek Paedagogi. Kurikulum 2013 
dengan aspek keguruan seorang guru harus disertai pengembangan yang lebih komprehensif baik secara mandiri maupun kelompok pada semua jenjang pendidikan. Hal ini didasarkan pada asumsi bahwa peserta didik dimasa yang akan datang akan menjadi masyarakat yang berciri akademik "society knowledge" yang bermodalkan kecerdasan, intelektual dan keterampilan memadai, namun tak hanya itu yang perlu diejawantahkan oleh guru dalam menghadapi kehidupan dimasa yang akan datang, emosional dan spiritual perlu terpadu diajarkan secara holistik dalam mata-mata pelajaran hal ini guna membekali peserta didik untuk selalu berpikir logis, dan rasional.

Pada kurikulum 2013 khususnya, secara aplikatif guru lebih diarahkan dalam berbagai kesempatan melakukan pengembangan pembelajaran mengintegrasikan teori dan realitas dalam perencanaan silabus tanpa merasa terbebani oleh teknis penyusunan. Nifasri Muh Nir Kasubdit PAI pada SMP mengatakan Inti perubahan dari kurikulum 2013 adalah perubahan mindset dimana guru sudah bukan lagi satu satunya sumber belajar tetapi guru menjadi fasilitator bagi peserta didik untuk mencari tahu. ${ }^{31}$ Strategi yang dapat dilakukan seperti pada pembelajaran tertentu guru diarahkan merancang secara spesifik suatu aktifitas pembelajaran yang untuk menumbuhkan rasa mencintai ilmu pengetahuan. Mengembangkan aktivitas keagamaan dalam prilaku kehidupan sehari-hari, menekankan kedisiplinan (tata tertib) di didalam maupun diluar sekolah. Selain itu guru penting melakukan penilaian terhadap dirinya sendiri sebagai sumber inspirasi dan dan sumber keteladanan.

Kedua, Optimalisasi peran antar stakeholder. Mengoptimalkan peran guru dalam kaitan ini ialah pentingnya kerjasama, dukungan, bimbingan dan pengawasan baik pemegang kebijakan, kepala sekolah, pengawas, tokoh masyarakat maupun praktisi pendidikan secara terpadu dan berkesinambungan. Hal ini memungkinkan terwujud optimal peran guru melalui kerjasama serta antar pihak. Beberapa contoh dalam kaitan ini misalnya, kedisiplinan dan penerapan kode etik guru, pengawasan terhadap moral dan akhlak guru dalam kehidupan sehari-hari yang diintegrasikan kedalam pembelajaran, dengan berpatokan pada kompetensi inti Kurikulum 2013. Persoalan moral menjadi mainstream dalam kehidupan global sehingga dianggap tantangan berat, guru wajib menjadi panutan sebab sumber masalah dalam dunia pendidikan dimasa kini ialah kedangkalan moral. Penguatan moral dan akhlak akan sangat penting diterapkan secara menyeluruh di dalam maupun di luar proses pembelajaran sehingga siswa mampu berprilaku sama. Selain itu pentingnya evaluasi guru pada berbagai aspek kehidupannya sehingga memiliki rancangan penyempurnaan, dengan mengacu tujuan pendidikan secara holistik.

\footnotetext{
mengisyaratkan kepada guru untuk memahami karakter setiap siswa dengan berpedoman bahwa setiap siswa memiliki keunikan karakter masing-masing dan harus dikembangkan secara maksimal. Sehingga setiap siswa memiliki hak untuk tuntas sampai menguasai kompetensi yang diharapkan dalam setiap pembelajaran. Maka guru berfungsi sebagai motivator dan fasilitator dalam pencapaian kompetensi. (4) Aspek kepribadian. Dalam kurikulum 2013 kepribadian guru menjadi sangat penting dalam pembentukan karakter, diharapkan guru selain menjadi motivator dan fasilitator di dalam kelas juga menjadi inspirator bagi siswa untuk berperilaku agar karakter yang diharapkan oleh undang-undang dapat diwujudkan. (5) Aspek sosial. Dalam kurikulum 2013, guru diharapkan dapat bersinergi dengan guru dalam mata pelajaran lain yang ada di sekolah. Hal ini menuntut kecerdasan sosial guru agar pendidikan integratif interkonektif dapat terwujud. Lihat, Endah Yuli Astanti, Perubahan Peran Guru dalam Kurikulum 2013: Analisis Konstruktif. Makalah Presentasi Perkuliahan. Tidak Diterbitkan, hlm. 8.

${ }^{31}$ Pengembangan Kurikulum PAI/Direktorat Jenderal Pendidikan Islam Kementerian Agama RI. Di akses tanggal 24 desember 2013.
} 


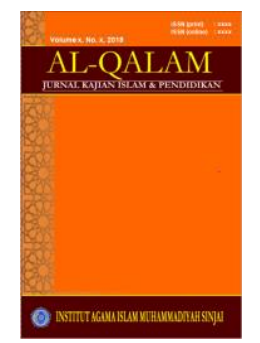

AL-QALAM

Jurnal Kajian Islam \& Pendidikan

Volume 8, No. 2, 2016

ISSN (print) : 1858-4152

ISSN (online) : xxxx-xxxx

Homepage : http://journal.iaimsinjai.ac.id/index.php/al-qalam

Ketiga, Optimalisasi peran sebagai anggota masyarakat. Peran guru dalam masyarakat merupakan substansi kompetensi sosial, setiap persoalan masyarakat menjadi bagian dari peran penting guru dalam pemecahan masalah. Masyarakat kini telah banyak berhadapan dengan problem sederhana hingga problem global yang sulit terindentifikasi oleh mayoritas khususnya guru sehingga diperlukan responsif dan kesiapan guru memposisikan diri sebagai solve baik melalui cara penguasaan dan penguatan keterampilan bahasa maupun menganalisa masalah hingga penyelesaiannya secara tepat.

Lingkup optimalisasi diatas perlu diiringi strategi seperti guru diharuskan memiliki referensi sebanyak mungkin baik dengan mengikuti dan pemanfaatan media tekhnologi informasi baik nasional dan global serta proaktif dalam pengembangan diri dengan adaptif dan aktualisasi. Selain itu berinovasi untuk dapat menjadi pioneer perubahan serta dinamis dalam proses perubahan peradaban. Dari hal ini guru akan bahkan mampu berprestasi secara global, dan bukan hanya murid atau siswa tertentu yang diarahkan dalam kompetisi global sebagaimana banyak raihan prestasi olimpiade-olimpiade tertentu, akan tetapi guru juga penting kompetitif dilevel global.

\section{KESIMPULAN}

1. Guru memiliki peran sentral dalam proses pendidikan hal ini didasarkan pada regulasi kebijakan yang tertuang dalam Undang-Undang No. 20 tahun 2003 tentang Sistem Pendidikan Nasional dan Undang Undang No.14 tahun 2005 tentang Guru dan Dosen. Undang-undang ini menitikberatkan pada peran dan tugas guru sebagai penyelenggara pendidikan. Peran sentralnya ini kompleks dengan tantangan globalisasi yang menyurutkan nyali guru dalam berkompetisi. Perubahan kebijakan dalam system pendidikan ini menegaskan pentingnya perubahan paradigma guru dalam proses pembelajaran khususnya pada kurikulum 2013. Mengamati peran guru di Indonesia dapat merujuk pada sejarah perkembangannya yang mengalami banyak dinamika seiring perkembangan zaman. Peran guru telah ada sejak pendidikan pondok pesantren disamping sistem yang dikembangkan oleh kolonial penjajah. Pra kemerdekaan hingga kemerdekaan (masa orde lama) hingga pasca kemerdekaan dan memasuki masa orde baru, guru adalah memiliki kewenangan sentral dalam pendidikan yang menanamkan jiwa nasionalisme dan pembangunan bangsa. Memasuki reformasi system pendidikan merubah paradigma guru dalam proses pembelajaran untuk proaktif pembentukan jiwa kemanusiaan selain transformasi ilmu pengetahuan sebagaimana konten kurikulum KTSP dan Kurikulum 2013. Proses pembelajaran didasarkan pada empat pilar yaitu learning to know, learning to do, learning to be dan learning to live together.

2. Kurikulum 2013 memiliki content yang mengintegrasikan pembelajaran dengan realitas peserta didik dalam artian mengubah penguasaan teori menjadi aksi nyata. Komponen pembelajaran menekankan pembentukan sikap, keterampilan, pengetahuan. Semua mata pelajaran diajarkan dengan pendekatan saintific dan penilaian otentik melalui mengamati, mencoba, menanya dan menalar, serta mengkomunikasikan. Kesiapan guru dalam implementasi ini belum mampu terpenuhi secara maksimal disebabkan perubahan sistem tanpa persiapan antar komponen pendidikan, pemahaman utuh terhadap substansi kurikulum, kemampuan menyusun rencana pembelajaran yang bermuatan karakter. Seharusnya memerlukan pendekatan sosialisasi secara merata, serta pengkajian 
perencanaan pembelajaran yang utuh dan komprehensif sangat penting oleh guru dilakukan secara mandiri dan kelompok.

3. Budaya global membuat perubahan dalam pendidikan secara simultan seperti perubahan sistem dan tujuan pendidikan, teknis pembelajaran dan perubahan substansi pendidikan. Hal ini dihadapi guru sebagai suatu tantangan multi kompleks yang dampaknya sangat terasa, diantaranya ialah berkaitan dengan nilai-nilai kehidupan yang dianut dan diterima oleh sebagian besar masyarakat dunia, hak-asasi manusia yang berkaitan dengan dimensi kemanusiaan secara global, tantangan profesionalisme dan kreatifitas guru untuk mampu berkompetisi dari lokal ke global, tantangan sekularisme, kapitalisme dan liberalisme dalam sendi-sendi pendidikan dan kehidupan masyarakat, lemahnya sikap dan kemampuan toleransi generasi bangsa dalam memperkokoh nilai ke-bhinneka tunggal ikaan.

4. Dalam kurikulum 2013 menformulasikan jangka panjang dalam pembentukan sikap, keterampilan dan pengetahuan peserta didik. Optimalisasi peranan guru mencakup lingkup pokok seperti; (1). Kompetensi guru yang berkaitan dengan paedagogik, kepribadian, sosial, professional serta kompetensi global. (2) Peran antar stakeholder, memonitoring peran guru dalam tugasnya. Kaitan ini seperti pentingnya kerjasama, dukungan, bimbingan dan pengawasan dari pemegang kebijakan, kepala sekolah, pengawas, tokoh masyarakat dan praktisi pendidikan secara terpadu dan berkesinambungan. (3). Peran guru sebagai anggota masyarakat. Peran guru dalam masyarakat merupakan substasi kompetensi sosial secara utuh, setiap persoalan masyarakat menjadi bagian dari peran penting guru dalam pemecahan masalah. Selain itu untuk dapat kompetitif dilevel global guru penting memiliki referensi secara maksimal dari media tekhnologi informasi, proaktif dalam pengembangan diri (perubahan mindset), adaptif dan aktualisasi, inovatif dalam pioneer perubahan serta dinamis dalam proses peradaban.

\section{DAFTAR PUSTAKA}

Asmani, Ma'mur, Jamal. Kompetensi Guru Menyenangkan dan Profesional, Yogyakarta, Power Books, 2009.

Astanti, Yuli, Endah. Perubahan Peran Guru dalam Kurikulum 2013: Analisis Konstruktif. Makalah Presentasi Perkuliahan. Tidak Diterbitkan

Hamalik, Oemar. Dasar-Dasar Pengembangan Kurikulum, Bandung: PT Remaja Rosdakarya, 2009.

Kementerian Pendidikan dan Kebudayaan dalam Mata Diklat:2, Analisis materi ajar jenjang: SD/SMP/SMA Mata Pelajaran: Konsep Pendekatan Scientific.

Kunandar, Guru Profesional, Jakarta:R aja Graphindo Persada, 2007.

Mastuhu, Menata Ulang Pemikiran Sistem Pendidikan Nasional dalam Abad 21, Yogyakarta: Safiriah Insania Press, 2004.

Muhaimin, Pengembangan Kurikulum Pendidikan Agama Islam; di Sekolah, Madrasah, dan Perguruan Tinggi, Jakarta : PT. Raja Grafindo Persada, 2005.

Mujib, Abdul. Ilmu Pendidikan Islam. Jakarta: Kencana Prenada Media, 2006. 


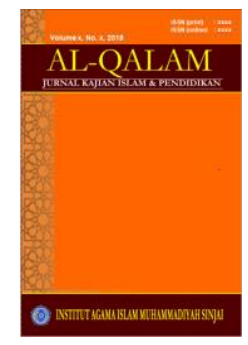

AL-QALAM

Jurnal Kajian Islam \& Pendidikan

Volume 8, No. 2, 2016

ISSN (print) : 1858-4152

ISSN (online) : xxxx-xxxx

Homepage : http://journal.iaimsinjai.ac.id/index.php/al-qalam

Mulyasa, E. Pengembangan dan Implementasi Kurikulum 2013, Bandung:Remaja Rosda Karya, 2013.

Natsir, Fatah, Nanat. "Peningkatan kualitas Guru dalam Perspektif Islam" dalam jurnal EDUCATIONIST No. I Vol. I Januari 2007.

Pendis, Dirjen. Pengembangan Kurikulum PAI. Direktorat Jenderal Pendidikan Islam Kementerian Agama RI.

Permendikbud No 68 Tahun 2013 Tentang Kerangka Dasar dan Struktur Kurikulum Sekolah Menengah Pertama/ Madrasah Tsanawiyah.

Putra, Ahimsa, Shry, Heddi. Sumber Nilai Budaya dan Nilai Budaya untuk Generasi Muda Indonesia, Makalah disampaikan dalam Kongres Pendidikan, Pengajaran dan Kebudayaan II, di Yogyakarta 5 Mei 2014.

Rahman, Munawar, Budhy. Sekularisme, Liberalisme, Pluralisme dan Islam Progresif Indonesia, Makalah Seminar di Convention Hall UIN Sunan Kalijaga Yogyakarta, tanggal 18 September 2013,

Ramayulis, Ilmu Pendidikan Islam Jakarta : PT. Kalam Mulia, 2004.

Ramayulis, Metodologi Pendidikan Agama Islam, Jakarta: Kalam Mulia, 2012.

Retnoningsih, Ana dan Suharso. Kamus Besar Bahasa Indonesia Edisi Lux, Semarang: Widiya Karya, 2011.

Sanjaya, Wina. Kurikulum dan Pembelajaran Teori dan Praktik Pengembangan Kurikulum Tingkat Satuan Pendidikan (KTSP), (Jakarta: Kencana Prenada Media Group, 2009.

Taba, Hilda. Curriculum Development, Theori and Practice, New York: Harcourt, Brace \& World, Inc, 1962.

Tafsir, Ahmad. Ilmu Pendidikan dalam Perspektif Islam, Bandung: Remaja Rosdakarya, 1992.

Undang-Undang tentang Guru dan Dosen Nomor 14 tahun 2005

Undang-Undang No. 20 tahun 2003 Tentang Sistem Pendidikan Nasional.

Umar dkk, Landasan Konseptual Pengembangan Kurikulum; Sebuah Tinjauan Kritis, Makalah tidak diterbitkan. Lihat juga Koran Harian Kompas, Rabu, 18 September 2013, dalam Mengupas Sisi Positif Kurikulum 2013.

Uno, B. Hamzah. Profesi Kependidikan, problem, solusi dan reformasi pendidikan di Indonesia, Jakarta: Bumi Aksara,

Website: Peran dan Fungsi Guru dalam website, http://edukasi.kompasiana.com /2012/07/18/. 